PROBLEMS

OF MANAGEMENT IN THE $21^{\text {st }}$ CENTURY Vol. 14, No. 1, 2019

\title{
HUMAN CAPITAL AS A DETERMINANT OF STRATEGIC HUMAN RESOURCES MANAGEMENT IN PUBLIC ADMINISTRATION ON THE EXAMPLE OF POLAND
}

\author{
Joanna Dzieńdziora \\ WSB University, Poland \\ E-mail: jdziendziora@wsb.edu.pl \\ Małgorzata Smolarek \\ University of Social Sciences, Poland \\ E-mail: msmolarek@san.edu.pl
}

\begin{abstract}
Human capital refers to all the competences of employees. It is a resource of knowledge, skills and attitudes existing in every human being and society as a whole, which defines capability of work and adaptation to changes in the environment, and possibility of creating new solutions. The paper is theoretical and empirical in nature and presents the role of human capital in the implementation of personnel policy in an organisation. The aim of the paper is to present diagnosis of the level of human capital that contributes to the implementation of personnel policy of public administration on the example of integration and welfare institutions examined. Empirical part of the paper presents analysis of the survey results within selected aspects of human capital management in the institutions examined. Primary data collected during a quantitative study using questionnaire surveys, with a survey questionnaire as a research tool. The questionnaire was addressed to randomly selected employees of public administration organizations of the type integration and welfare institutions located in Silesian Voivodeship (Poland). Results of research: in the area of a strategy for human capital management there is a clear lack of a comprehensive approach which would enable a consistent use of modern tools for human capital management in this type of institutions.
\end{abstract}

Keywords: human capital, human resources management, public administration.

\section{Introduction}

Human capital is the driving force of an organisation. Creativity and creative thinking, as well as involvement in work, allow organisations to develop and achieve effects of their activities. It is people - aware of their competences and necessity of improving them, not only in the professional field - that constitute the pillar of an organisation. Human capital of an organisation is a factor that determines the achievement of competitive advantage on the modern market, while a feature of human capital is human capability of learning and constant development of possessed knowledge. As shown in further analysis, the organisation analysed takes every effort to strengthen its capital, i.e. people employed in it.

Due to lack of comprehensive reports and analyses diagnosing the state of the process of managing human resources in public administration in Poland, the general aim of the research 
project was to diagnose the state of human resource management taking into account its impact

on the functioning of integration and welfare institutions, and to indicate areas of improvement in the model under diagnosis.

\section{Theoretical Background}

In economics theory, there are two basic approaches to human capital which are Macroeconomic approach and Microeconomic approach. Microeconomic Approach to human capital is based on business economics and managerial views (Alika \& Aibieyi, 2014).

Academic literature provides numerous definitions of human capital in Microeconomic approach. According to the most frequently quoted definition, "human capital is a resource of knowledge, skills, health and vital energy, existing in every human being and society as a whole, determining capability of work, adaptation to changes in the environment and possibilities of creating new solutions." This definition stresses the role of human capital in dynamically developing and changing environment in the area of creativity and innovativeness (Sung, Sun Young, Choi, \& Jin Nam, 2018).

Davenport and Prusak (1998) see human capital as the innate abilities, behaviours, personal energy possessed by people and these elements make up the human capital which they bring to the workplace. To Armstrong (2009) human capital is the knowledge and skills which individuals create, maintain and use. New theories of economic growth characterized the human capital as the sum of the individual congenital and acquired skills, knowledge, and experiences of individuals. OECD defines human capital as knowledge, skills, abilities, and other characteristics that are relevant for economic activity (Kucharcikova, 2011).

These aspects are becoming particularly important in a knowledge-based economy (Ployhart, Nyberg, Reilly, \& Maltarich, 2014), where success is determined by easy adaptation to the conditions of operation in a turbulent environment, the so-called adaptability to changes (Sipa, 2017). Innovative approach to managing people in an organisation stresses: decisive contribution of human capital to creation of an organisation's value and determining its competitive position, treatment of people as profit leverage, rather than as a mere element of costs, management of the development of employees - development is a form of joint investment of employees and employers, flexible and dynamic management as a paradigm of the 21 st century (Juchnowicz, 2007). Academic literature recommends that investment in human capital is most important for achieving higher level of economic growth which gives raise to the per capita income and higher level of slandered of living (Greer, Lusch, \& Hitt, 2017).

The formation of human capital takes place as part of the personnel function of an organisation, which involves such stages as: human capital planning, recruitment of employees, evaluation, development and remuneration of employees, communication or human relation building. The main areas of value creation in the area of the use of human capital are: work organisation, management, motivation, effectiveness management, employee evaluation and communication. However, every organisation should strive to ensure that human capital is effectively used in the process of work. Appropriate use of human capital should bring an organisation measurable effects (Dzieńdziora \& Smolarek, 2010).

Both the theory and practice provide increasing proof confirming the thesis that human capital is the most important of an organisation's assets. However, the measurement of the value of human capital still causes a lot of problems, both methodological and practical ones. Human capital, especially nowadays, is characterised by dynamically increasing importance of knowledge at all levels of social and economic life and is regarded as the main factor influencing economic growth and development, both of countries and societies. An important issue connected with human capital is to identify processes determining its creation and its later use (Gorzeń-Mitka, 2017; Łukasiewicz, 2009). Organisations that manage human capital focus mainly on the process of knowledge use, which is manifested in supporting ideas and improvements put forward by employees, and cooperation with business partners aimed at improve- 
Joanna DZIEŃDZIORA, Małgorzata SMOLAREK. Human capital as a determinant of strategic human resources management in public administration on the example of Poland

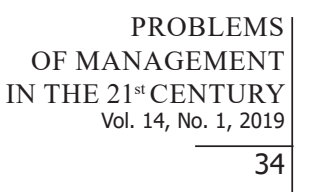

ment of offered products and services. Such organisations also focus on adaptation of structures and hierarchy so that they don't prevent employees from accessing knowledge.

There are two parties that participate in the process of accumulation of an organisation's human capital: the employee and organisation. Employees can increase their knowledge and skills through education, additional training courses outside the organisation and experience gained during work. Organisations that want to increase their value by increasing human capital of their members may use various strategies. i.e. ensure it is created in the organisation or acquire it on the market. Human capital acquired on the market represents accumulation of expenditures of an employee and expenditures incurred by the previous employer in order to increase knowledge and skills of this employee. In turn, human capital created in an organisation increases its value as well as the value of earlier expenditures incurred by the previous employer. Gaining experience by working in an organisation, an employee increases their individual human capital and their value on the market (Król \& Ludwiczyński, 2010).

Care about people means attracting, keeping, developing and motivating an appropriate group of employees, as well as support in creating an appropriate culture and climate of an organisation. It requires strategic approach, in which it is recognised that the potential of an organisation depends on its resources. It is however necessary to focus not only on the needs of an organisation in terms of human resources, but also on the needs of people themselves. It should be noted that every organisation is a community composed of entities representing different interests, which should be identified and respected (Armstrong, 2010). The organizational culture influence on the loyalty and commitment of employees is particularly evident in the family business.

From the theoretical and practical perspectives, it is highly important to establish the relationships between human resources and human capital of an organisation - whether and thanks to what human resources can become human capital. A strategy of converting human capital into an organisation's capital takes various forms of long-term decisions, which focus on: adapting employment to changing conditions of the environment (Israelsen \& Yonker, 2017), exerting an impact on the environment, organising expert groups around personnel units, rewarding for effective work and shaping the internal labour market (Król \& Ludwiczyński, 2010).

Management of human resources is an area that requires the use of numerous practices, tools and procedures. The last years saw a significant evolution of the personal function in an organisation. Nowadays, we observe huge diversity of personal procedures and their random use. Although we can distinguish basic stages in the development of a personal function, it is difficult to determine the level of actual development of personal practices observed in organizations. It highlights the importance of strategic HRM for organisational learning in uncertain task environments to promote organisational transition [Hu, Hao' Wu, Jihong, Shi, \& Jianchang, 2016).

Traditional personnel management and human resources management activities are not enough to compete in the challenging environments (Bal, Bozkurt, \& Emtersir, 2014). Human resources management is an aspect that addresses how an enterprise will implement its objectives through people, strategic measures and integrated rules for the operation. It is based on three postulates: human resources fulfil a strategic role in ensuring success to an organisation and are one of the main sources of its competitive advantage; human resources strategies should be consistent with the economic plans of organisations and individual human resources strategies should be consistent with each other so that they strengthen each other. Miller argues that HR strategies should be integrated with corporate strategies. For this integration, the management measures in the field of human resources should be coordinated and synchronized with other areas of the organization's activities (Miller, 2006).

A human resources management is not only strategic planning, but above all the implementation of tasks which are in line with an organisation's strategy as well as all strategic decisions and actions of HR specialists in cooperation with other managers of an organisation 
$\mid \begin{aligned} & \text { PROBLEMS } \\ & \text { OF MANAGEMENT } \\ & \text { IN THE } 21^{\text {st }} \text { CENTURY } \\ & \text { Vol. } 14, \text { No. } 1,2019\end{aligned}$

(Ahearne, Lam, \& Kraus, 2014). Any decisions have a long-term impact on an organisation's actions and its future success. For strategic management of human resources to be effective, a few basic principles should be taken into account: human resources are of significant importance for the implementation of the existing general objectives, human resources are taken into account in the process of developing a strategy of an organisation and the existing effective and constant relationships ensure the inclusion of activities connected with human resources in the decision making process, at all levels of an organisation, concepts initiated in the area of human resources are connected with the needs of an organisation; human resources management is responsible for the decisions and actions based on which an organisation undertakes economic activities. A successful HCM strategy requires specific groundwork and execution to support workforce performance (Tucker, 2018). Strategic human resources management is based on two principles (Colbert, 2004). First is the belief regarding the vital strategic importance of the organization's human resources. This explains the idea that every employee's personal traits, talent, behaviour and interaction possess an inner potential in formulating basic strategies and more importantly, putting strategies into practice. Second is the thought that in order to bring up strategic strength in the organization, the HRM practices are certainly utilizable (Gilani, Zadeh, \& Saderi, 2012).

Recent advancements and improvements in HRM systems across the developing countries connote yet again the significant role of HRM as a strategic means to improve organizational performance (Condrey \& Ledvinka, 2010).

Traditionally public administration systems tend to have a centralized personnel management. Organizations (institutions and agencies) have a relatively low chance to choose their personnel management system freely and develop it; they are obliged to function according to the current civil service law. It also ensures coordinated actions of organizations, objectivity and precision as well as high professionalism, but it also creates flaws such as bureaucracy, delays, and the inability to adapt to changes in external environment in time (Sarnovics, 2010).

Effective management of human resources in public administration requires the incorporation of human resources development and continuous and strategic planning for "the right person for the right job" (Covell, 2011). Human resources management in public administration can only be effective if it focuses on the theoretical and practical foundation of the public administration, which is an academic field (Ronquillo, 2008), a field of scientific management and application (Van Riper, 1995); a field of managerial professionalism (Fry \& Nigro, 1996), and a field of legal and political processes (Drechsler, 2000).

In public organizations, it can be argued, the human resource management function serves an added role as a steward of democracy. It ensures that employees are treated fairly and equitably, that diversity within the organization reflects the diverse populations in the society at large, and that public jobs are open to all qualified citizens (Ingraham, 2005). Key driver for the achievement of higher levels of public administration employees' productivity is considered the employment of a suitable performance appraisal system. Based on this perspective, we assume that every organization needs to establish an effective appraisal system which will be sufficient to facilitate employees' continuous development. This is especially relevant for public sector organizations that in some countries implement fundamentally flawed performance appraisal systems (Isychou, Chountalas, Magoutas, \& Fafaliou, 2016). The application of advanced administrative theories (i.e. New Public Management, Public Governance etc.) and best management practices requires the transition from the bureaucratic public administration to an effective, flexible public management (Boyle, 2006). It has become clear that it would be extremely useful to implement an effective system of measurement and management of performance (Pidd, 2012). However, it should be noted that the actions of the public sector cannot be attributed solely to monetary terms, due to its multidimensional mission. Therefore, the recording and analysis of administrative efficiency is necessary, aiming at the continuous improvement of the existing level of service and the employees' skills (Behn, 2003). Each human resource evaluation system should be based on a carefully designed scorecard system and 
Joanna DZIEŃDZIORA, Małgorzata SMOLAREK. Human capital as a determinant of strategic human resources management in public administration on the example of Poland

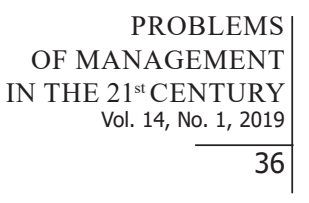

PROBLEMS
OF MANAGEMENT

$21^{\text {st }}$ CENTURY

36

performance management through specific targets (Kreitner, 2009). Also, closely related to performance appraisal are the issues of employee selection and rewards. Both employee selection and rewards are enabled by an effective appraisal system. The reward and benefits management is about rewarding people fairly and equitably in consistence to the value of the organization so as to assist the organization to achieve its strategic goals (Armstrong, 2006).

The final HR value, creating standards for improved ethical behaviour in public organizations, ranks among the most significant concerns in today's public sector environment (Daly, 2015).

\section{Research Methodology}

The research included diagnosis of human resource management performed based on an analysis of the management process, resulting from the level and involvement of the managerial staff and work quality, which is closely connected with employees' competences and potential, which in turn impacts the quality of working environment and organisational culture. The factors presented were treated as direct causes of the effectiveness and efficiency (or their lack) of the process of human resources management in integration and welfare institutions. Organisational units of the institutions in which the survey was conducted include: regional centres for social policy, district (poviat) family support centres, social assistance centres, social care centres, centres offering specialist advisory services, including family counselling, assistance centres and crisis intervention centres. 154 people participated in the survey $(n=154)$.

The methodology presents only those research problems on which this paper concentrates. The detailed objectives of the research included: 1 . Identification of the needs of integration and welfare institutions in the area of the process of human resources management. 2. Characterisation of phenomena that have a positive or negative impact on the process of human resources management in the institutions under analysis.

The following research problems were formulated, among other things: 1 . Are strategies implemented in an appropriate way in integration and welfare institutions? 2. Do the institutions under analysis have comprehensive strategies in place in the area of human capital management?

As part of the research the following research areas were diagnosed: strategic management of human capital, employment planning, selection of employees, building relations in an organisation, remuneration and motivation system and an employee appraisal system. This paper concentrates on selected issues in the areas: strategic approach to human capital management.

In order to receive reliable results, literature studies were complemented by analysis of original data obtained during a quantitative study using a questionnaire survey with a survey questionnaire as the research tool. The questionnaire was addressed to randomly selected employees of integration and welfare institutions based in Silesian Voivodeship (Poland). The questionnaire was sent to 1000 employees of integration and welfare institutions in the period February-April 2018. The survey resulted in 167 completed questionnaires, of which 154 completely and correctly filled in questionnaires were accepted for further analysis.

\section{Research Results}

Organisational units of social services in which the research was conducted include: regional centres for social policy, district (poviat) family support centres, social assistance centres, social care centres, centres offering specialist advisory services, including family counselling, assistance centres and crisis intervention centres. 154 people participated in the survey, of which females accounted for $87 \%$, males constituted $11.7 \%$ (in the other cases - no data was provided). All those surveyed had higher education. As far as age is concerned, people aged $25-35(53.2 \%)$ and $36-45(36.4 \%)$ dominated. $7.8 \%$ of them were aged $46-55$, whereas $2.6 \%$ 
Joanna DZIEŃDZIORA, Małgorzata SMOLAREK. Human capital as a determinant of strategic human resources management in public administration on the example of Poland

were at the age of 25. As far as the seniority is concerned, the biggest group consisted of the respondents with 5 to 10 years of work experience in integration institutions and social services

PROBLEMS

OF MANAGEMENT

IN THE $21^{\text {st }}$ CENTURY

Vol. 14, No. 1, 2019 (48.1\%). Work experience of 11 to 20 years was declared by $32.5 \%$ of those surveyed, up to 5 years of work experience - by $15.6 \%$, from 21 to 30 years - by $2.6 \%$, whereas the rest $(1.3 \%)$ had over thirty-years' work experience in such institutions. $42.2 \%$ of those surveyed fulfilled managerial functions, whereas $57.8 \%$ - operational functions.

Strategic approach to human capital management enables a consistent use of modern tools for human capital management in an organisation. It leads to a close integration of the different systems for management of human resources, which significantly increases their effectiveness.

In the area of strategic management of human resources, the following hypotheses were formulated, among other things: $H_{l}$. In integration and welfare institutions, strategies are implemented in an inappropriate way. $H_{2}$. The institutions examined often do not have comprehensive strategies in the area of human capital management.

Integration and welfare institutions have visions of their future development $(76.0 \%)$. Little over $30.0 \%$ of those surveyed confirmed that their institutions had such a vision in the form of a specific project, whereas $50.0 \%$ admitted that the development vision of their organisation was not a specific project, but mere plans that have not been fully thought out (Figure 1).

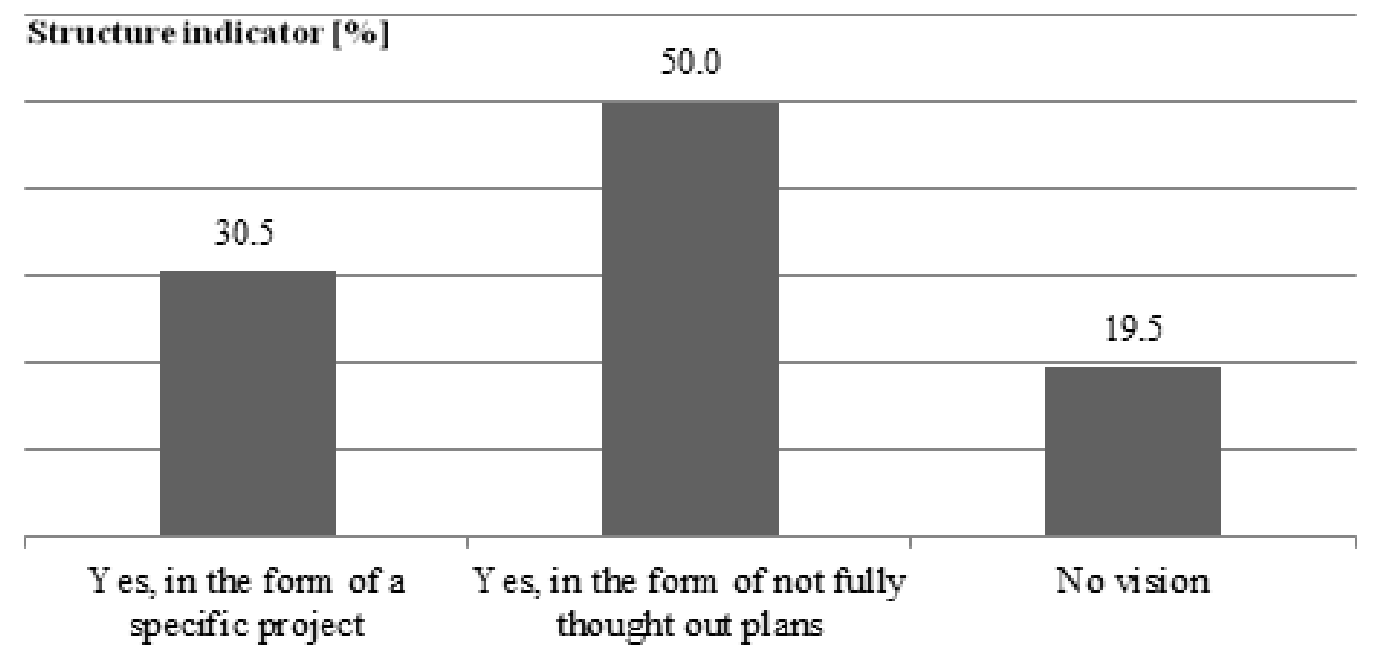

Figure 1. Vision of organisation future development.

These results overlap with those referring to possession of strategies by the institutions examined $(66.9 \%)$ - Figure 2. In most cases, employees of institutions with a vision of the future are aware of the existence of such a strategy and know its assumptions. In turn, organisations without a vision also have no strategy, or employees are not aware of it. The knowledge of the basic assumptions of the strategy is declared by $60.4 \%$ of employees of the institutions examined. It should be stressed that this percentage is too low. Such assumptions should be known to all employees, rather than part of them (employees fulfilling managerial functions are more familiar with these assumptions than those fulfilling operational functions). In the case of employees in managerial posts, these assumptions are known to $78.4 \%$ of respondents, whereas in the case of operational posts, this figure is only $19.1 \%$. 
Joanna DZIEŃDZIORA, Małgorzata SMOLAREK. Human capital as a determinant of strategic human resources management in public administration on the example of Poland
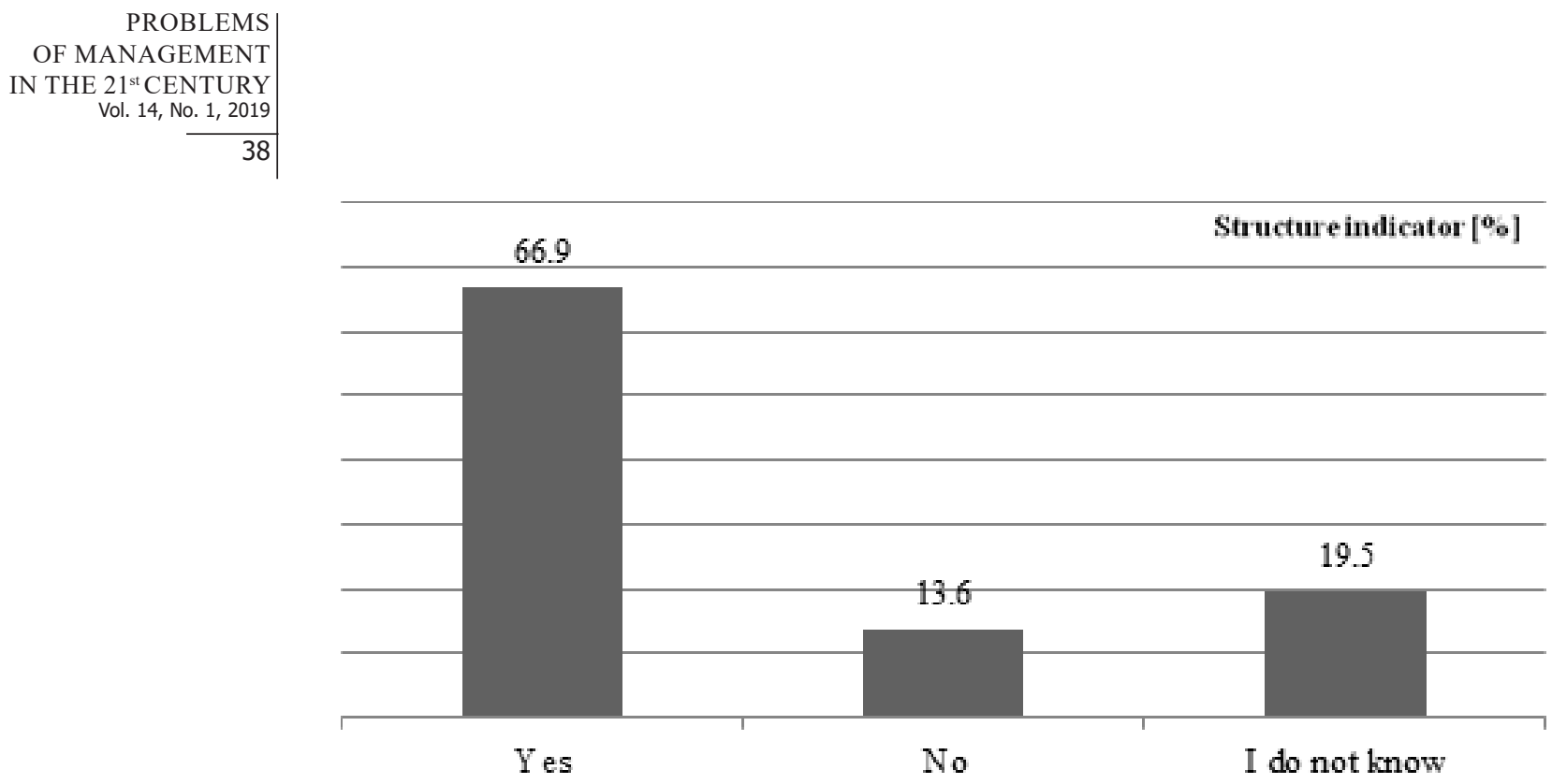

Figure 2. The organization has a strategy.

Asked about clarity and intelligibility of the objectives of their institution, 59.1\% of the respondents answered that the objectives were formulated in a clear and intelligible way, whereas, unfortunately, as many as $40.9 \%$ claimed that they did not understand the objectives their institution wanted to achieve. This may mean failure to implement the strategy in an appropriate way. One of the basic conditions of an appropriate implementation of a strategy is to ensure that employees understand its objectives. If employees do not understand the objectives, it is difficult for them to contribute to their achievement through appropriate performance of tasks.

The strategies of organisations usually covered the period of over 3 years $(49.5 \%)$. According to $41.7 \%$ of respondents, strategies in their institutions were developed for the period of 2-3 years, whereas according to $7.8 \%$ - for around a year (Figure 3). No strategy covered a period shorter than one year. Long-term strategies have to be more general due to changeability of the environment. Therefore, a very important issue and at the same time an important condition for an organisation to achieve its objectives is to make them specific and cascade them to tasks, which have specific addressees. However, asked: whether the tasks performed to achieve the objectives have their addressees (whether there are people responsible for their performance) $64.9 \%$ of the respondents answered that the tasks had their addressees, but as many as $35.1 \%$ indicated lack of such addressees. This is highly worrying as it suggests inappropriate implementation of a strategy and may lead to failure to achieve objectives of an institution which are very important from the perspective of implementing social goals of our country. These results confirmed hypothesis $\mathrm{H}_{1}$. 
Joanna DZIEŃDZIORA, Małgorzata SMOLAREK. Human capital as a determinant of strategic human resources management in public administration on the example of Poland

PROBLEMS

OF MANAGEMENT

IN THE $21^{\text {st }}$ CENTURY

Vol. 14, No. 1, 2019

$49.5 \%$

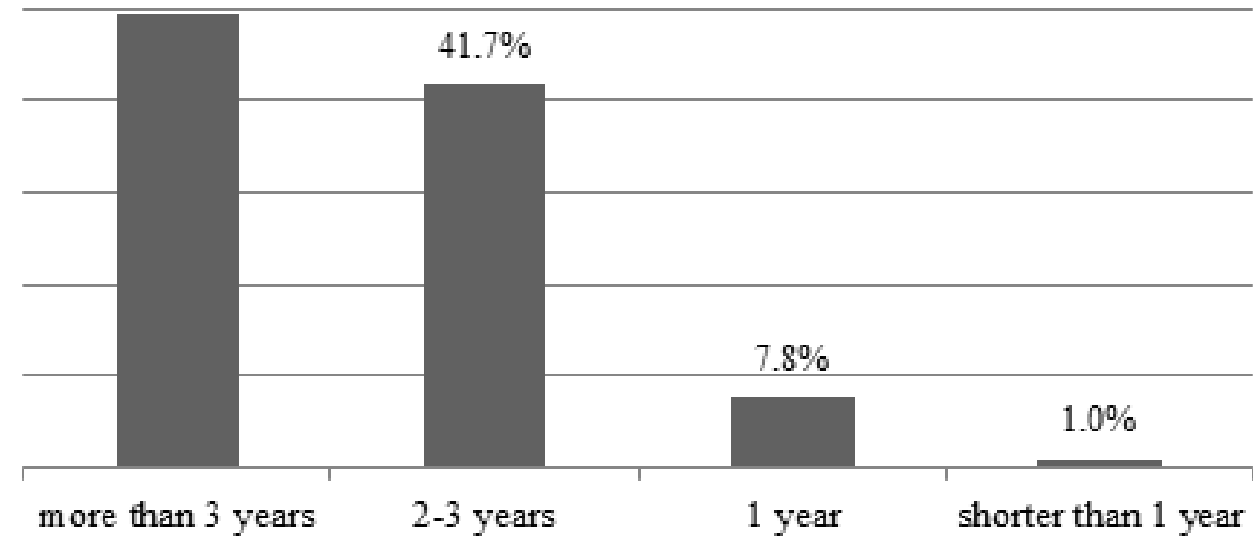

Figure 3. The period of the strategy.

In the area of a human capital management strategy, $66.9 \%$ of those surveyed indicated lack of such a strategy, and the rest $33.1 \%$ indicated the contrary. The respondents working in the institutions with a strategy for human resources management usually indicated that this strategy referred to the area of employee appraisal, staff planning and staff selection (Figure 4). This confirms hypothesis $\mathrm{H}_{2}$.

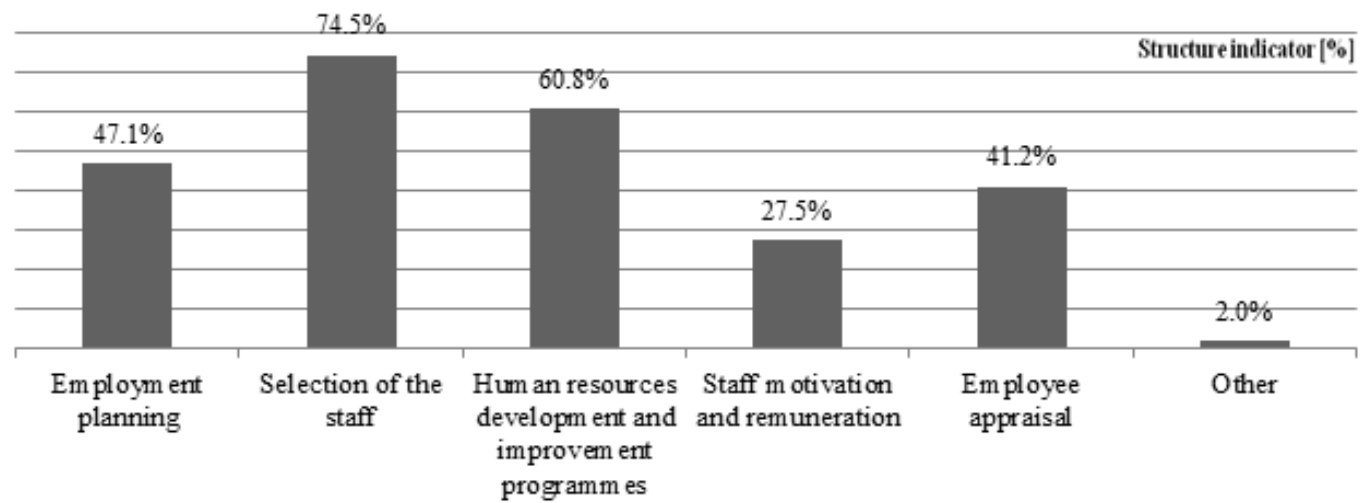

Figure 4. Areas of the strategy for human resources management.

\section{Conclusions}

Management of human resources requires organisation of the cooperation among an organisation's members so that their abilities and skills are put into appropriate use and behaviour that decreases the effectiveness of an organisation is neutralised. Management requires that members of an organisation communicate with each other and with the environment. Communication is a tool for management, setting objectives and making people have similar objectives.

In Poland public administration organizations of the type integration and welfare institutions have a vision of future development and strategy of action for the future. Unfortunately, employees' knowledge of its basic assumptions is too poor. The assumptions of such a strategy should be known to all employees, not only to those fulfilling managerial functions. We can also observe failure to appropriately implement the strategy. One of the basic conditions for a strat- 
Joanna DZIEŃDZIORA, Małgorzata SMOLAREK. Human capital as a determinant of strategic human resources management in public administration on the example of Poland

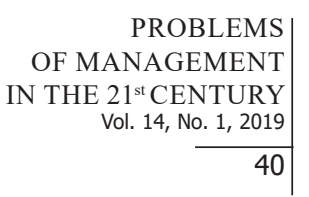

40

egy to be appropriately implemented is for employees to understand objectives to be achieved.

This condition is not fulfilled in the institutions surveyed.

Summing up, in the area of a strategy for human capital management there is a clear lack of a comprehensive approach which would enable a consistent use of modern tools for human capital management in this type of institutions. There is no integration between the different systems for human resources management that would increase their effectiveness.

\section{References}

Ahearne, M., Lam, S. K., \& Kraus, F. (2014). Performance impact of middle managers' adaptive strategy implementation: The role of social capital. Strategic Management Journal, 35, 68-87.

Alika, I. J., \& Aibieyi, S. (2014). Human capital: Definitions, approaches and management dynamics. Journal of Business Administration and Education, 5 (1), 55-78.

Armstrong, M. (2006). A handbook of management techniques: A comprehensive guide to achieving managerial excellence \& improved decision making. London: Kogan Page Publishers.

Armstrong, M. (2010). Strategiczne zarzadzanie zasobami ludzkimi [Strategic management of human resources]. Warszawa: Wolters Kluwer.

Armstrong, M. (2009). Armstrong's handbook of human resource management practice, 11 th ed., London: Kogan Page Ltd.

Bal, Y., Bozkurt, S., Emtersir, E. (2014). A study on determining the relationship between strategic HRM practices and creating innovation in organizations. International Journal of Contemporary Management, 13 (2), 23-36.

Behn, R. D. (2003). Why measure performance? Different purposes require different measures. Public Administration Review, 63(5), 586-606.

Boyle, R. (2006). Measuring public sector productivity: Lessons from international experience. CPRM Discussion Paper 35, Institute of Public Administration (IPA), Dublin.

Colbert, B. A. (2004). The complex resource-based view: Implications for theory and practice in strategic human resource management. Academy of Management Review, 29(3), 341-358.

Condrey, S. E., \& Ledvinka, C. B. (2010). Human resource management in the public sector: Examining international cases. Public Administration Review, 70(3), 500-501.

Covell, C. (2011). Human resources management for effective public administration. Chinese Public Administration Review, 6(3/4), 61-81.

Daly, J. L. (2015). Human resources management in the public sector. Policies and practices. New York: Routledge, p. 8.

Davenport, T. H., \& Prusak, L. (1998). Working knowledge. Cambridge: HBS Press.

Drechsler, W. (2000). Public administration in Central and Eastern Europe: Considerations from the "State Science" approach. In Castro, Burlamaqui, Chang, (Eds.), Institutions and the role of the state (pp. 267-279). Cheltenham - Northampton, Mass: Edward Elgar.

Dzieńdziora, J., Smolarek, M. (2010). Kapitał ludzki w kreowaniu kapitału intelektualnego organizacji [Human capital in creating the intellectual capital of the organization]. Zeszyty Naukowe Wyższej Szkoty Humanitas w Sosnowcu, 2, 82-95.

Fry, B. R., \& Nigro, L. G. (1996). MaxWeber and US public administration: The administrator as neutral servant. Journal of Management History, 2(1), 37-46.

Gilani, M. H. N., Zadeh, M. S., \& Saderi, H. R. (2012). The role of strategic human resource management in creation of competitive advantages (Case study: A commercial organization in Malaysia). International Journal of Business and Social Science, 3(16), [Special Issue - August], 225-238.

Gorzen-Mitka, I. (2017). Bricolage concept in risk culture assessment. European Journal of Sustainable Development, 6 (1), 335-343. doi: 10.14207/ejsd.2017.v6n1p335.

Greer, Ch. R, Lusch, R. F, \& Hitt, M. A. (2017). A service perspective for human capital resources: A critical case for strategy implementation. Academy of Management Perspectives, 31(2), 137-158.

Hu, H., Wu, J., \& Shi, J. (2016). Strategic HRM and organisational learning in the Chinese private sector during second-pioneering. International Journal of Human Resource Management, 27(16), 18131832.

Ingraham, P. W. (2005). Performance: Promises to keep and miles to go. Public Administration Review, 65(4), 390-395. 
Joanna DZIEŃDZIORA, Małgorzata SMOLAREK. Human capital as a determinant of strategic human resources management in public administration on the example of Poland

Israelsen, R. D., \& Yonker, S. E (2017). Key human capital. Journal of Financial and Quantitative Analysis, 52(1), 175-214.

Isychou, D., Chountalas, P., Magoutas, A., \& Fafaliou, I. (2016). Human capital and performance appraisal in the public sector: An empirical investigation from employees' and senior managers' perspective, MPRA Paper No. 72405, Online at https://mpra.ub.uni-muenchen.de/72405/.

Juchnowicz, M. [ed.] (2007). Elastyczne zarządzanie kapitatem ludzkim w organizacji wiedzy [Flexible human capital management in the organization of knowledge]. Centrum Doradztwa i Informacji Difin, Warszawa.

Kreitner, R. (2009). Management. Boston: Houghton Mifflin Harcourt.

Król, H., \& Ludwiczyński, A. [ed.] (2010). Zarządzanie zasobami ludzkimi. Tworzenie kapitału ludzkiego organizacji [Human resource management. Creating the human capital of the organization] (pp. 116-117). Warszawa: Wydawnictwo Naukowe PWN.

Kucharcikova, A. (2011). Human capital - Definitions and approaches. Human Resources Management \& Ergonomics, 5(2), 60-70.

Łukasiewicz, G. (2009). Kapitał ludzki w organizacji. Pomiar i sprawozdawczość [Human capital in the organization. Measurement and reporting]. Warszawa: Wydawnictwo Naukowe PWN.

Miller, D. (2006). Strategic human resource management stores. Journal of Retailing and Consumer Services, 13, 99-109.

Pidd, M. (2012). Measuring the performance of public services: Principles and practice. Cambridge: Cambridge University Press.

Ployhart, R. E., Nyberg, A. J., Reilly, G., \& Maltarich, M. A. (2014). Human capital is dead: Long live human capital resources. Journal of Management, 40, 371-398.

Ronquillo, J. C. (2008). Establishing a locus of native American governance in academia? An interdisciplinary approach to informing public administration research. Presented at the 2008 Native American and Indigenous Studies Association (NAISA) Conference. Athens, Georgia, April 10-12.

Sarnovics, A. (2010). Human resources development in public administration: A case of Latvia. Human Resources Management \& Ergonomics, 4(1), 1-12.

Sipa, M. (2017). Innovation as a key factors of small business competition. European Journal of Sustainable Development, 6 (1), 344-356.

Sung, Sun Young, \& Choi, J. N. (2018). Building knowledge stock and facilitating knowledge flow through human resource management practices toward firm innovation. Human Resource Management, 57(6), 1429-1442. https://doi.org/10.1002/hrm.21915.

Tucker, E. (2018) Secrets to success: Human capital management strategy. Strategic HR Review, 17(4), 170-175.

Van Riper, P. P. (1995). Luther Gulick on Frederick Taylor and scientific management. Journal of Management History, 1(2), 6-7.

Received: April 16, 2019

Accepted: June 18, 2019

PROBLEMS

OF MANAGEMENT

IN THE $21^{\text {st }}$ CENTURY

Vol. 14, No. 1, 2019 